\title{
25 vuotta Idäntutkimusta
}

Idäntutkimus täyttää tänä vuonna 25 vuotta. Lehteä julkaiseva Venäjän ja Itä-Euroopan tutkimuksen seura VIETS oli perustettu viisi vuotta aiemmin, 1989, ja viettää tänä vuonna siis jo 30-vuotisjuhlaansa. Kun Idäntutkimus vuonna 1994 alkoi ilmestyä, lehden tarkoituksena oli, kuten Venäjän ja Itä-Euroopan tutkimuksen seuran pitkäaikainen sihteeri Anneli Virtanen kirjoitti 10-vuotisjuhlanumerossa 2004, "seurata oman tutkimusalansa kehitystä, tarjota mahdollisuus meritoivien artikkelien tuottamiseen ja toimia yhdyssiteenä seuran hallituksen ja jäsenistön välillä”. Tarve Venäjää ja itäistä Eurooppaa käsittelevälle tutkimustiedolle, myös yleistajuisessa muodossa, oli 1990-luvun alussa iso. Idäntutkimuksen erityispiirteenä on edelleenkin akateemisen tutkimuksen ja populaarin aineiston yhdistäminen samaan lehteen. Nykypäivänä tilaajista noin puolet on muita kuin VIETSin jäseniä.

Perustamisvaiheessa Idäntutkimus-lehdessä suunniteltiin julkaistavan muun muassa tieteellisiä artikkeleita, puheenvuoroja ja kirja-arvioita. Myös kotimaisten väitöskirjojen esittelyä pidettiin tärkeänä.

Venäjän ja itäisen Euroopan tutkimuksessa on näkynyt tieteenalan kattaman maantieteellisen alueen laajeneminen, vaikka suurin osa Idäntutkimukseen tarjottavista artikkeleista käsitteleekin Venäjää. Pitkällä aikavälillä tarkasteltuna julkaisussa näkyvät erilaisten tutkimusprojektien elinkaaret ja toisaalta yksittäisten tutkijoiden ja tutkimusryhmien pitkäaikaiset kiinnostuksen kohteet.

Muutoksia on tapahtunut myös esimerkiksi kielikäytännöissä. 1990-luvulla lehdessä julkaistiin suomenkielisten sisältöjen lisäksi venäjän- ja englanninkielisiä artikkeleita. Lehden uudistuksen jälkeen Markku Kangaspuron aloitettua päätoimittajana 2000-luvun alkuvuosina kieleksi vakiintui suomi. Nykyään tutkimuksen kansainvälisyys näkyy muun muassa käännösartikkeleissa; tavallisimmat artikkelien alkukielet näissä ovat juuri englanti ja venäjä.

Suomenkielisyyteen perustuva malli toi lehden entistä laajemman lukijakunnan ulottuville. Kuten VIETSin hallituksen puheenjohtajana vuosina 1998-2003 toiminut Kimmo Kääriäinen juhlanumerossa 2004 kirjoitti, harva lukee monisataasivuista väitöskirjaa, mutta moni kuitenkin lukee mielellään sen keskeiset tulokset Idäntutkimuksesta. 
Idäntutkimuksessa vakiintunut käytäntö julkaista uusinta tutkimusta teemanumeroissa tukee sitä, että eri tutkimusalat saavat monipuolisesti näkyvyyttä. Samalla teemat pyritään määrittämään sellaisiksi, että niihin sopii mukaan tutkimusta eri tieteenaloilta. Tämä osaltaan tuo lisää sävyjä keskusteluun lehden maantieteellisen kohdealueen yhteiskunnista. Näemme toimituskunnassa tärkeänä julkaista teemoitettujen numeroiden ohella aika ajoin myös teemaltaan vapaita numeroita, jotta myös sellainen tutkimus joka ei solahda lähiaikojen lehtiin suunniteltujen teemojen alle, voi päästä esiin.

Tämänkertaisessa, niin ikään teemaltaan vapaassa numerossa saamme muun muassa perehtyä Eeva Kuikan artikkelin avulla siihen, miten neuvostoajan vaikutus arktisen alueen ihmisten ja eläinten väliseen suhteeseen näkyy tšuktšikirjailija Juri Rytheun tuotannossa. Laura Saarenmaa puolestaan käsittelee artikkelissaan Kalle-lehden matkakertomuksissa ilmaistuja käsityksiä ja asenteita Neuvostoliittoa ja sen etupiiriin kuuluneita sosialistimaita kohtaan. Vielä neuvostoaikaa kauemmas historiaan matkaamme Tomi Huttusen artikkelissa, joka tekee lähiluvun mystistä kääntäjä- ja välittäjäpersoonaa, herra Grosswaldia käsittelevistä sanomalehtiuutisista 1800-luvun loppupuolelta.

Vuonna 2004 julkaistuissa katsauksissa kymmenvuotiaan lehden taipaleeseen sähköinen julkaiseminen ei ollut vielä keskustelunaiheena. 2000-luvun mittaan siitä on kuitenkin tullut yksi tieteellisen julkaisemisen suurimmista muutoksista, joka koskee luonnollisesti myös tätä lehteä. Viimeaikaisia ilonaiheita tällä saralla on ollut internet-sivujemme uudistus, mihin liittyen Idäntutkimuksen arkisto 2000-luvun alkuvuosiin asti on nyt avoimesti saatavilla osoitteessa journal.fi/idantutkimus.

Tarkoitus on jatkossakin tarjota vapaasti luettaviksi vuosi sitten ja sitä aiemmin julkaistut numerot. Uusimmista numeroistakin on näytejuttuja saatavilla. Olemme myös siirtyneet vastaanottamaan uudet artikkelikäsikirjoitukset verkkosivun kautta. Verkkosivuja kehitetään edelleen, ja niistä kuten muistakin lehteä koskevista asioista otamme toimituskunnassa mielellään palautetta, kehittämisehdotuksia ja juttuideoita vastaan - yhteystietomme löytyvät lehden alusta.

Hyvää kesää!

Helsingissä 12.6.2019

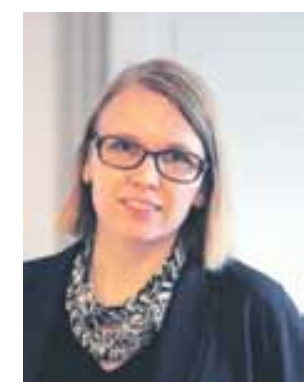

Katja Lehtisari 